\title{
L1 and L2 Reading Strategies Connection: A Review of Past Studies
}

\author{
Yuan Xin \\ Dr. Fauziah Bt Ismail \\ Dr. Azian Bt Abd Aziz@Ahmad
}

Language Academy, Universiti Teknologi Malaysia; yxuibe@126.com

\section{Doi:10.5901/mjss.2016.v7n1s1p306}

\begin{abstract}
This study reviews past studies in first language (L1) strategies and second language (L2) strategies comparison. The similarities of strategies in both languages can be seen in the transfer of L1 strategies in L2 reading; however, the extent of transfer and the type of strategies being transferred are varied in different studies. The differences in strategies across languages lie mainly in the overall number and frequency of strategies and the preferred strategy types. Suggestions for future research are also provided at the end of the study.
\end{abstract}

Keywords: reading, strategies, first language, second language, connection

\section{Introduction}

How L1 reading and L2 reading are related has been examined in a plethora of studies in the past (Grabe and Stoller, 2013). Among them, some studies are comparing $L 1$ and $L 2$ reading strategies as they serve as important indicators of reading processes (Yau, 2009; Lin and Yu, 2013). However, these studies are varied in participants, L2 proficiency level of participants, and their findings. It is necessary to compare these studies and summarize and compare their findings. This study aims to examine studies on L1 and L2 reading strategies over the past and focuses on two aspects: 1) the transfer of L1 strategies in L2 reading; 2) the overall strategy use pattern in both languages.

\section{Review of Past Literature}

This section firstly discusses method and criteria in selecting past literature on the research topic: connection of L1 and $L 2$ reading strategies. Past research has also been classified into different categories with regard to the transfer of L1 strategies in $\mathrm{L} 2$ reading.

\subsection{Criteria in Source Selection}

The selection of sources or past literature is based on the following criteria: 1) all the studies are closely relevant to the research topic: L1 and L2 reading strategies connection; 2) most studies are up-to-date: out of the 10 selected studies, 7 of them (70\%) were conducted after 2003, with 6 out of the 7 conducted after 2005; 3) all selected studies were of highquality, with 7 out of 10 (70\%) studies published in high-ranking journals based on data from "The SCImago journal and country Rank" (a portal that includes the journals and country scientific indicators developed from the information contained in the Scopus ${ }^{\circledR}$ database)

\subsection{Literatures Supporting Conditional L1 Reading Strategies Transfer}

This section discusses studies which are in favor of transfer of L1 strategies in L2 reading. Taillefer and Pugh (1998) view second language (L2) proficiency as a prerequisite condition for the transfer of first language (L1) strategies in L2 reading. Thirty nine French students were divided into three groups based on their strength or weakness on two independent variables: L1 reading proficiency and L2 language competency. The study found that only for the group strong at both variables (Str-Str group), the strategic approach is similar and the transfer of strategies seems automatic with positive behavior maintained at 93\% level in passing from L1 to L2.However, groups weak on either one or both 
variables move strategically from good to poor or from poor to worse.

Taillefer and Pugh (1998)'s findings were echoed in the study conducted by Tsai et al. (2010) who found distinctive pattern of L1 and L2 reading strategies for skilled and less skilled readers (Based on their scores on L2 proficiency tests). For skilled readers, no significant difference were found among all five categories of reading strategies across languages, suggesting a smooth transfer of $L 1$ reading strategies in $L 2$ reading. For the less skilled readers, on the other hand, major difference were found in nearly all five categories of strategies between two languages, indicating different reading processes in L1 and L2.

The two studies above both found a large degree of strategy transfer in nearly all categories for skilled readers. The less skilled readers, however, were hindered by their low L2 proficiency and unable to transfer effective L1 reading strategies in L2 reading. This finding is in line with the threshold hypothesis (Cummins, 1976) which believes a threshold level of $\mathrm{L} 2$ proficiency must be obtained for the transfer of $L 1$ reading skills or strategies in $L 2$ reading.

However, some studies found transfer of certain type of strategies even among low proficiency L2 readers. Davis and Bistodeau (1993) compared English and French reading strategies for two groups of participants, the native reader of English (NRE group) and the native reader of French (NRF group). In the NRE group, participants with shorter L2 learning experience and at undergraduate level, three times more top down than bottom up strategies were found in L1 as compared to $L 2$, suggesting limited L2 proficiency might prevent the transfer of higher-level strategies. However, no significant difference existed among the metacognitive comments for NRE group, proving similar pattern of metacognitive strategy pattern in both L1 and L2 regardless of participants' L2 proficiency. In the NRF group, participants with longer L2 learning experience and studying at postgraduate level demonstrated similar strategy pattern across languages. Mean proportion of top down strategies were significantly higher as compared to bottom up strategies regardless of language for NRF group.

Consistent with previously mentioned studies, Davis and Bistodeau (1993)'s study found large degree of L1 strategy transfer among proficient L2 readers and low degree of L1 cognitive strategy transfer for less proficient L2 readers. However, the transferability of L1 metacognitive strategies is not hindered by low L2 proficiency, providing contradictory results to threshold hypothesis.

Similar to Davis and Bistodeau (1993)'s findings, Yau (2009) in the study on Taiwanese adolescent's L1 and L2 reading strategies found significant correlation between strategy use in L1 and L2 reading, supporting the common underlying proficiency (Cummins, 1979). Relatively high correlation between the use of metacognitive strategies across languages was also detected, suggesting the transfer of metacognitive strategies regardless of L2 proficiency level. Highperforming readers in this study were found to be better able to apply effective L1 strategies in L2 reading as compared to low-performing readers due to their enhanced awareness on the interaction of $L 1$ and $L 2$ reading. One thing worth noting in this study is the similar strategic approach found in reading classical Chinese texts and English texts.

Other studies also proved the existence of strategy transfer to different extent. Pearson et al. (1996) explored the reading strategies adopted by successful and less successful Latina/o readers in English and Spanish. Four types of transferred strategies were identified for successful readers: questioning, rereading, evaluating and monitoring indicating an enhanced awareness of the relationship between two languages for successful readers. The less successful readers were found unable to apply knowledge of Spanish to enhance English comprehension and vice versa.

Kong (2006) explored reading strategies employed by 4 ESL Chinese learners in reading both English and Chinese. Some common and transferable reading strategies were found across languages including using text structure, invoking prior knowledge and evaluating reading content. The most frequently used strategies in both languages are applying text structure knowledge and knowledge of themselves and the content knowledge in figuring out the author's point of view. All participants demonstrated different degrees of strategy transfer across languages and participants with higher L2 proficiency level might find it easier to transfer higher-level cognitive and metacognitive strategies as compared to participants with lower L2 proficiency level.

Maarof and Yaacob (2011) also detected certain degree of L1 strategy transfer for secondary Malaysian students at varying English proficiency level with some common types of strategies found in both $L 1$ and $L 2$ reading. However, the study failed to categorize the strategies being transferred and did not mention any difference in strategy transfer across different L2 proficiency groups. The results of this study also could not be generalized due to limited number of participants (9).

Lin and Yu (2013) compared L1 and L2 reading strategies for English as foreign language (EFL) college students at varying reading levels in Taiwan. Participants in this study demonstrated similar preference pattern in three reading strategy categories. The use of metacognitive strategies, in particular, were found readily shared across languages, which is in line with previously mentioned studies (Davis and Bistodeau, 1993; Yau,2009). Higher-proficiency group employed more effective metacognitive strategies as compared to lower-proficiency group in their L2 reading which is line 
with previously mentioned studies (Davis and Bistodeau ,1993; Yau,2009; Pearson et al. ,1996).

The above 8 studies share something in common: 1) they all recognize large degree or some degree of L1 strategies transfer in $L 2$ reading; 2) most of these studies recognized the active role of $L 2$ proficiency in strategy transfer from L1 to L2. However, these studies are varied in some aspects: 1) the extent of strategy transfer: large extent of transfer of strategies in all categories were found in some studies while only a few types of transferrable strategies were detected in other studies; 2) the type of participants for L1 strategy transfer: some studies believe only participants with threshold L2 proficiency level were able to transfer all types of L1 strategy in L2 reading, while other studies view metacognitive strategies transferrable for all participants, regardless of their L2 proficiency level. Table 1 briefly summarizes the findings of the 8 studies in terms of strategy transfer.

Table 1. L1 Strategy Transfer in L2 Reading

\begin{tabular}{|c|c|c|c|}
\hline Authors & Participants & $\begin{array}{l}\text { Types of participants for L1 } \\
\text { strategy transfer }\end{array}$ & Types of transferred strategies \\
\hline Taillefer and Pugh (1998) & $\begin{array}{l}39 \text { French students with varying L1 and } \\
\text { L2 proficiency }\end{array}$ & $\begin{array}{l}\text { Participants strong at both L1 } \\
\text { and L2 }\end{array}$ & $\begin{array}{l}\text { General strategies } \\
\text { Local problem-solving strategies }\end{array}$ \\
\hline Tsai et al. (2010) & 222 Taiwanese EFL undergraduates & Skilled $\mathrm{L} 2$ readers & $\begin{array}{l}\text { Textual content } \\
\text { Concrete technique } \\
\text { Task perception } \\
\text { Problem solving }\end{array}$ \\
\hline $\begin{array}{l}\text { Davis and Bistodeau } \\
\text { (1993) }\end{array}$ & $\begin{array}{l}8 \text { Native English readers (NRE) and } 8 \\
\text { native French readers (NRF) with better } \\
\text { L2 proficiency }\end{array}$ & NRE and NRF & $\begin{array}{l}\text { Top-down, bottom-up and metacognitive } \\
\text { strategies for NRF } \\
\text { Metacognitive strategies for NRE }\end{array}$ \\
\hline Yau (2009) & 144 grade-11 students & $\begin{array}{l}\text { Skilled and less skilled } \\
\text { readers }\end{array}$ & Cognitive, metaconitive, support strategies \\
\hline Pearson et al (1996) & $\begin{array}{l}11 \text { successful and less successful } \\
\text { Latina/o readers }\end{array}$ & successful Latina/o readers & $\begin{array}{l}\text { questioning, rereading, evaluating and } \\
\text { monitoring }\end{array}$ \\
\hline Kong (2006) & 4 ESL Chinese learners & $\begin{array}{l}\text { Different degree of transfer } \\
\text { among all participants }\end{array}$ & $\begin{array}{l}\text { using text structure, invoking prior } \\
\text { knowledge and evaluating reading content }\end{array}$ \\
\hline Maarof and Yaacob (2011) & $\begin{array}{l}9 \text { secondary Malaysian students at } \\
\text { varying English proficiency level }\end{array}$ & All participants & $\begin{array}{l}\text { Skimming, slowing down, paying close } \\
\text { attention and other support strategies }\end{array}$ \\
\hline Lin and Yu (2013) & $\begin{array}{l}36 \text { EFL Taiwanese college students at } \\
\text { varying reading level }\end{array}$ & All participants & Metacognitive strategies \\
\hline
\end{tabular}

\subsection{Literatures Disproving of or Uncertain about Strategy Transfer}

Despite above mentioned studies supporting L1 strategy transfer in L2 reading, there are a few studies disprove or uncertain about strategy transfer from L1 reading to L2 reading. Pritchard and O'Hara (2008) studied strategy use among 20 native Spanish speakers with proficient English and Spanish reading proficiency. Contradictory to other studies, proficient bilingual readers in this study were found to process their L2 reading in a word-by-word manner, not being able to transfer high-level monitoring strategies into their $L 2$ reading.

In 1997, Tang explored 8 Chinese EFL students' strategy use in Chinese and English. Though a similar strategy use pattern was detected in this study, the author was not sure about any transfer of strategies as he did not investigate which strategy or strategies were specifically developed in L1 and L2.

The two studies mentioned above revealed the complexity of L1 strategy transfer in L2 reading. In addition to L2 proficiency, the text type might exert extra influence on reading strategy choice (Pritchard and O'Hara, 2008). In the meantime, more precise procedure needs to be developed to investigate strategies specifically developed for L1 and L2 for bilingual readers. Table 2 gives brief information on the above mentioned two studies.

Table 2. Studies Disproving or Uncertain about Strategy Transfer

\begin{tabular}{|l|l|l|}
\hline Authors & Participants & Strategy Transfer \\
\hline Pritchard and O'Hara (2008) & $\begin{array}{l}\text { 20 native Spanish speakers with proficient English } \\
\text { and Spanish reading proficiency. }\end{array}$ & $\begin{array}{l}\text { No transfer of high-level comprehension of } \\
\text { monitoring strategies }\end{array}$ \\
\hline Tang (1997) & 8 Chinese EFL students & Uncertain \\
\hline
\end{tabular}




\section{Analysis on the Results of Past Studies}

This section is going to summarize and compare the strategy use pattern in L1 and L2 reading in the above mentioned studies.

Despite a similar strategy use pattern in L1 and L2 reading was found in most studies, difference in specific strategy use difference was also detected in these studies. The difference was mainly in the following aspects: 1) overall number and frequency of strategy use; 2) preferred strategy type. Table 3 lists the specific similarities and differences in reading strategy use in both $\mathrm{L} 1$ and $\mathrm{L} 2$.

Table 3. Strategy Use Similarities and Differences in L1 and L2 Reading

\begin{tabular}{|l|l|l|}
\hline Authors & Strategy Use Similarities & Strategy Use Difference \\
\hline $\begin{array}{l}\text { Davis and } \\
\text { Bistodeau (1993) }\end{array}$ & $\begin{array}{l}\text { Similar pattern for higher L2 proficiency group } \\
\text { Similar metacognitive strategy use pattern for both } \\
\text { groups }\end{array}$ & Higher strategy transfer was inhibited by limited L2 proficiency \\
\hline $\begin{array}{l}\text { Schoonen and } \\
\text { Glopper (2003) }\end{array}$ & Similar strategy use pattern & $\begin{array}{l}\text { Considerable proportional difference : lower content-oriented } \\
\text { strategies and higher proportion of above-clause strategies in L2 }\end{array}$ \\
\hline Kong (2006) & Transfer of strategies to certain degree & $\begin{array}{l}\text { Much more explicit strategy in L2, much more vocabulary-related } \\
\text { strategy in L2 }\end{array}$ \\
\hline Tang (2006) & Similar strategy use pattern & Greater number of and more frequent strategy use in L2 \\
\hline $\begin{array}{l}\text { O'Hara (2008) } \\
\text { Yau(2009) }\end{array}$ & Did not mention & $\begin{array}{l}\text { More monitoring and content-oriented strategies in L1, less } \\
\text { monitoring and more sentence specific strategies in L2 }\end{array}$ \\
\hline Tsai et al. (2010) & Retatively similar pattern for skilled readers and & $\begin{array}{l}\text { metacognitive and cognitive strategies preferred in L1, support } \\
\text { strategies preferred in L2 }\end{array}$ \\
\hline Lin and Yu (2013) & Similar metacognitive strategy use pattern & $\begin{array}{l}\text { Different pattern among less skilled readers } \\
\text { preferred in L2, fewer cognitive strategies in L2 }\end{array}$ \\
\hline
\end{tabular}

Table 3 reveals the fact that despite transfer of $\mathrm{L} 1$ strategies in $\mathrm{L} 2$ reading to certain extent, differences between $\mathrm{L} 1$ and $\mathrm{L} 2$ reading strategies were found in most studies. Five studies noted the difference in preferred strategy type in L1 and $\mathrm{L} 2$, suggesting readers tend to use more higher-level, top-down strategies in their native language while more lower-level, bottom-up strategies in second language. Three studies found more frequent and diverse strategy use in L2.

\section{Conclusion and Suggestion for Future Research}

A review of past studies suggest that the connection of $L 1$ and $L 2$ reading strategies exist in the way that $L 1$ strategies are transferred to L2 reading to different extent. However, reading strategies in both languages are also different in overall number, frequency and proportion. Dispute still exist on the extent of L1 reading strategy transfer, type of L1 strategies being transferred, the role of L2 proficiency in L1 strategy transfer, and difference in overall number, frequency and preferred type of strategies in both languages. One possible reason behind the dispute might be the difference in participants and the categorization of strategies. More comparable studies are needed to investigate strategies employed in L1 and L2 reading for participants sharing similar L2 proficiency level and background knowledge.

\section{References}

Cummins, J. (1976). The Influence of Bilingualism on Cognitive Growth: A Synthesis of Research Findings and Explanatory Hypotheses. Working Papers on Bilingualism, No. 9.

Cummins, J. (1979). Linguistic interdependence and the educational development of bilingual children. Review of educational research, $49(2), 222-251$.

Davis, J. N., \& Bistodeau, L. (1993). How do L1 and L2 reading differ? Evidence from think aloud protocols. The Modern Language Journal, 77(4), 459-472.

Grabe, W. P., \& Stoller, F. L. (2013). Teaching and researching: Reading(2nd ed.). New York:Routledge.

Kong, A. (2006). Connections between L1 and L2 readings: Reading strategies used by four Chinese adult readers. The Reading Matrix, $6(2), \quad 19-45$.

Lin, L. C., \& Yu, W. Y. (2013). A think-aloud study of strategy use by EFL college readers reading Chinese and English texts. Journal of Research in Reading, 38(3), 286-306

Maarof, N., \& Yaacob, R. (2011). Meaning-making in the first and second language: reading strategies of Malaysian students. ProcediaSocial and Behavioral Sciences, 12, 211-223. 
Jiménez, R. T., García, G. E., \& Pearson, P. D. (1996). The reading strategies of bilingual Latina/o students who are successful English readers: Opportunities and obstacles. Reading Research Quarterly, 31(1), 90-112.

Pritchard, R., \& O'Hara, S. (2008). Reading in Spanish and English: A comparative study of processing strategies. Journal of Adolescent \& Adult Literacy, 51(8), 630-638.

Stevenson, M., Schoonen, R., \& Glopper, K. D. (2003). Inhibition or compensation? A multidimensional comparison of reading processes in Dutch and English. Language learning, 53(4), 765-815.

Tsai, Y. R., Ernst, C., \& Talley, P. C. (2010). L1 and L2 strategy use in reading comprehension of Chinese EFL readers. Reading Psychology, 31(1), 1-29.

Tang, H. (1997). The relationship between reading comprehension processes in L1 and L2. Reading Psychology: An International Quarterly, 18(3), 249-301.

Yau, J. L. C. (2009). Reading characteristics of Chinese-English adolescents: knowledge and application of strategic reading. Metacognition and Learning, 4(3), 217-235. 